\title{
Operation of car turbochargers - selected problems
}

\author{
Hubert Wojciechowski ${ }^{1,{ }^{* 1}}$, Czesław Żdanowicz ${ }^{2}$, Tony A. Hope ${ }^{3}$ \\ ${ }^{1}$ UTP University of Science and Technology in Bydgoszcz, Faculty of Mechanical Engineering, \\ Poland \\ ${ }^{2}$ BNTU University of Minsk, Faculty of Mechanical Engineering, Belarus \\ ${ }^{3}$ Southampton Institute, U.K
}

\begin{abstract}
In order to increase the filling of the cylinder in the engine, a socalled charge is applied, which consists in increasing the amount of air input under increased pressure and at an unchanged temperature. This increases the density of that air and increases the mass in the engine cylinder. In most cars, the charging is carried out by an exhaust gas turbocharger or a mechanical compressor. This paper presents the issues that concern the failure of turbochargers resulting from their balance by weight reduction method. Selected aspects concerning consequences of incorrect balancing and methods of reducing unbalanced rotor mass. A key part of the work includes a proposal to balance turbochargers of automotive vehicles using the "weight-adjustment"method. In this scope, preliminary studies were presented, and conclusions observed during their implementation were described.
\end{abstract}

\section{Introduction}

Modern internal combustion engines are characterized by the downsizing (decrease in engine capacity, while maintaining high engine power) and aim to achieve the best overall efficiency [4].

These trends can be met by using mainly a turbo-charging system in the drive unit. The principle of the engine charging system is relatively simple and consists in injecting more air into the cylinder in order to burn the petrol-blend more efficiently. The turbocharger or compressor is responsible for this process. In this way, the engine produces more power, which improves vehicle performance.

Car companies use mechanical turbo-charging in their models - compressors, as well as turbocharging. The second option is much more commonly used because of its universality. They are installed in compression ignition engines, spark ignition engines and hybrid cars. The turbocharger is the basic and at the same time the main element in the system of turbocharging $[1,3,8]$. It consists of three basic elements [3]: center hull, in which there is a bearing turbocharger rotor, turbine hull and compressor hull.

The basis of the efficiency of the turbines is the fact that they are able to pump a very large amount of air into the cylinder, and in addition they are powered by exhaust gas energy, which is not used in any way in naturally aspirated engines. The turbo-charging system has a significant influence on performance, so a noticeable power decrease can be one of the symptoms of turbocharger damage, especially if the problem is mainly related to the rotational range in which the turbine is most active. The technical sources are usually rotor damages, bearing damage and, in the case of turbines with variable geometry, hydraulic steering wheels.

\footnotetext{
*Corresponding author: hubert.wojciechowki@utp.edu.pl
} 


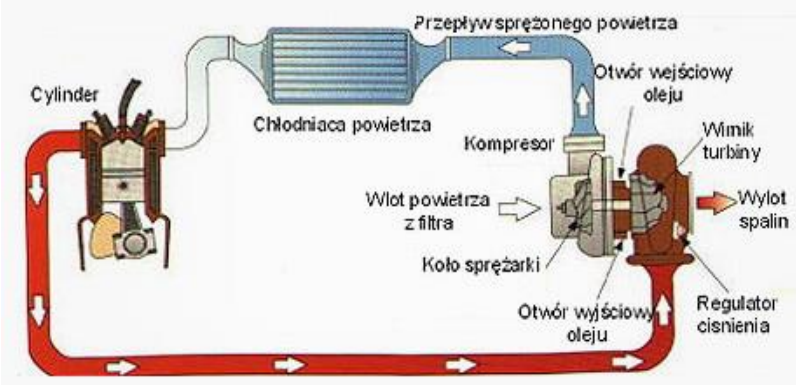

Fig. 1. Working principle of the turbocharger [2].

The turbocharger principle is based on the exhaust gas drive of the turbine rotor. The turbine is connected by a common shaft with a compression wheel, on which the air is aspirated. The compressed air is supplied to the combustion chamber of the engine cylinder under pressure - Fig. 1. To increase the efficiency of the turbocharger, an air cooler (intercooler) is used. Cooled air increases its density, which results an increase in the mass delivered to the combustion chamber.

Publications and scientific articles in this area of research discuss outside the typical operational defects of turbochargers do not focus on their faults, which are result from the methods of turbo-charging equipment regeneration [10,12]. Despite the huge popularity of engine turbo-charging systems for modern motor vehicles, manufacturers of turbochargers do not reveal the materials from which given components are constructed and do not provide information about theirs mechanical and physical properties[4]. Defects of the turbochargers components have a negative impact on the emission of harmful exhaust gases to the environment $[10,11]$. Description and modelling of the dynamic state, methods of diagnosing the state as well as the application of modern information techniques in turbochargers' research is so far hardly recognized and requires immediate improvement [8 ,11,12]. Literature describing the dependence of the method of regeneration and mainly balancing the turbocharger components -on the operation of the turbo-charging system is still very insignificant in this field. Existing publications so far describe mainly the balancing of turbochargers by means of a reduction method - taking off unbalanced mass and focusing mainly on damage to turbochargers resulting from improper operation of the turbo-charging device. Examples of this are the following articles: Balancing of turbocharger rotor [10], Damage analysis of turbocharger compressors [12], Analysis of the impact of operating conditions on the technical condition of turbocharger turbochargers of combustion engines [11]. Under heading [1] engine turbo-charging, general information can be found on, inter alia, balancing turbochargers using the' mass capturing' method.

This article presents the main causes of turbocharger damage, emissions in motor vehicles. The present methods of verifying the condition of charging devices have also been described and an innovative method of balancing turbochargers by "adding mass" has been proposed.

For the turbochargers regeneration, apart from the correct replacement of worn parts and the cleaning of other parts, the most important thing is the precise dynamic balancing of the rotating parts of the turbine.

\section{Diagnostic tester - verification of actual parameters}

In order to eliminate the undesirable condition of the turbocharger such as its failure, it is necessary to correctly identify and evaluate in detail the technical condition of the turbocharger by available ways. The simplest and at the same time lowest effective method of diagnosing turbocharger is organoleptic. Turbo-charging devices are evaluated with human senses. An oiled turbocharger may indicate a broken housing, damaged seals or a worn out 
suction section of the turbocharger. The organoleptics make it possible to hear disturbing sounds from the device. The damaged turbocharger is characterized by rustling, whistle. This can be indicated damaged, broken turbocharger rotor and a clogged cable between the inlet and intake manifold $[1,3,7]$.

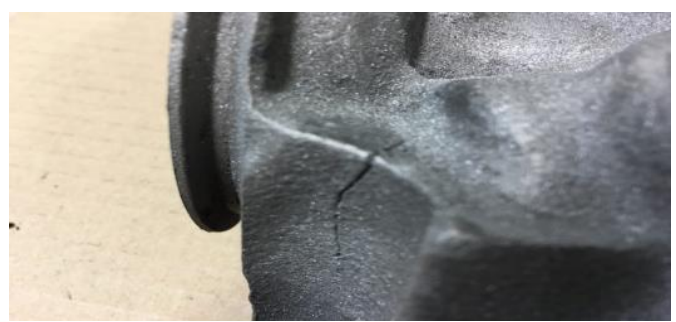

Fig. 2. Fracture of the outer part of the housing.

The color of the exhaust gas coming out of the exhaust system may also indicate the condition of turbo- charging device. The blue or black colour of the exhaust gases can indicate a turbocharger failure. This defect may indicate a cracked compression wheel or a defective oil system in the turbocharger. The presented method is one of the simplest, but in case of its credibility it becomes questionable because it does not ensure accuracy and insight in its assessment [10].

The parameter that characterizes turbo- charge system and can indicate its condition is the pressure of turbo-charging. The vehicle directive that has been drawn up stipulates that cars manufactured after 2000 must have 16-pin diagnostic connector. This makes it easier to diagnose any drivers emissions in a vehicle and the reading of operating parameters in any time unit.

The key information in the turbo-charging circuit is the actual data, which is stored by signals from sensors in the circuit. The evaluation of the above parameters is possible through additional functions, which are used as applications in diagnostic testers. An excellent example of this solution is the dashboard function in IDC5 software in the TEXA TXT's Tester. The turbo-charge pressure is checked here depending on [5]:

- rotor speed,

- compressed air pressure,

- exhaust gas temperatures,

- the blade angle of inclination in the variable geometry system.

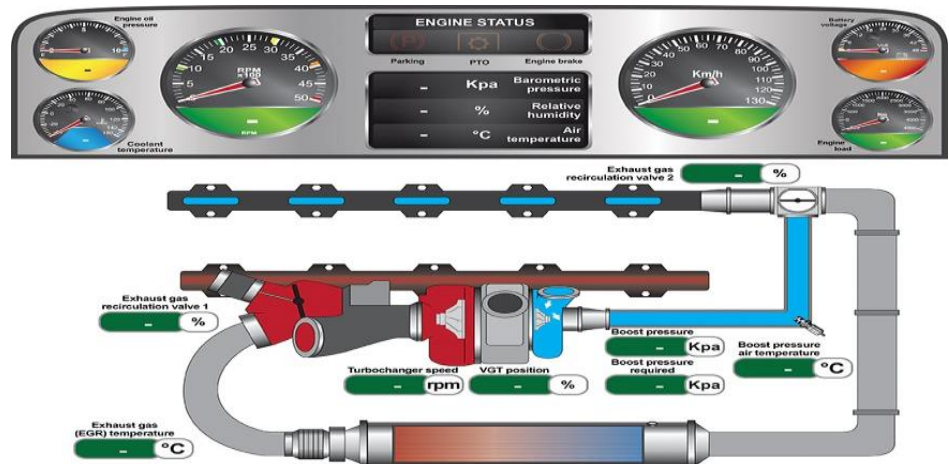

Fig. 3: DASHBOARD application in IDC5 software [5].

One of the main reasons of failure of turbochargers is unbalance of its rotating parts. To measure the balancing quality of the turbocharger's rotor we use two types of devices:

- quick-rotating turbocharger core correction machines (fig.4), 
- $\quad$ slow rotating devices for balancing the turbocharger shaft (Fig. 5).

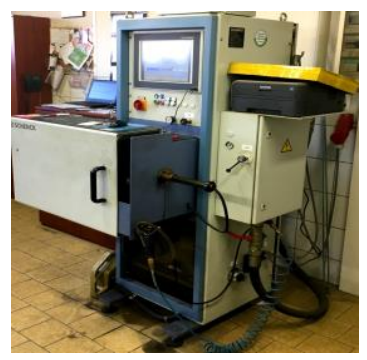

Fig.4. Core correction machine.

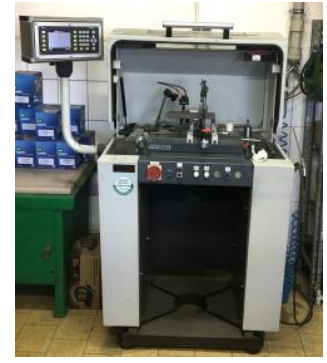

Fig.5. Rotor balancing machine.

The presented devices verify turbochargers in the context of unbalance measurements of rotor masses and correct the balance of turbine wheel and compression wheel with turbocharger shaft. Unbalanced weight is reduced with an accuracy of $0,01 \mathrm{mg} / \mathrm{mm} 2$ and the unbalance tolerance value is assigned to a given type of turbocharger and stored in the internal memory of the device. Unquestionably, the above method is one of the most accurate, precise methods of verifying turbo-charging devices.

\section{Methods of identyfying the consition of turbochargers}

Due to higher and higher operating speeds of turbochargers, even a minor unbalance causes an increase of vibrations, which in consequences may lead to a quicker damage of the whole component. The effect of its use is subsequent vibrations of rotors, causing much faster wear of bearings, rings and other parts of turbochargers.

Balancing is the process of checking the distribution of the rotor mass and correcting it, if necessary, until residual unbalance is obtained within the set tolerances. The aim is to achieve an even weight distribution of the rotor with respect to its geometric axis of rotation. In theory, the unbalance of rotating elements can be divided into three basic types: static, momentary and dynamic. In practice, we are dealing with all of them simultaneously, but the division applied makes it easier to understand the essence of the phenomena taking place and to choose a rational method of limiting their negative results.

\subsection{Dynamic balancing of the rotor by the 'mass reduction' method}

The main reason for damage and failure of turbo-charging devices is unbalance of turbocharger's rotor. Rotor unbalance creates excessive vibrations which are transmitted to the machine body, which leads to damage to the roller bearings. A characteristic feature of the rotor unbalance is a regular increase in bearing vibration amplitude, which depends on the rotational speed of the rotor of the turbo-charging device. These are always harmonic vibrations, the frequency of which is equal to the frequency of rotor rotation. Rotational speed of turbocharger rotor oscillates around $200000 \mathrm{rpm}$, so the problem of natural frequency is particularly important. The absolute condition of the turbocharger's usefulness is not showing a tendency to any vibrations, whether the drive unit rotates or not $[2,6,12]$.

Unbalance of basic components of the turbocharger may lead to various damages and even serious failures [3,9]:

- damage to the turbine wheel blades and compression,

- cracks in the turbocharger shaft,

- damage to radial cotact ball bearings and thrust bearings,

- jamming and damage of turbocharger's rotor,

- variable geometry system failure. 


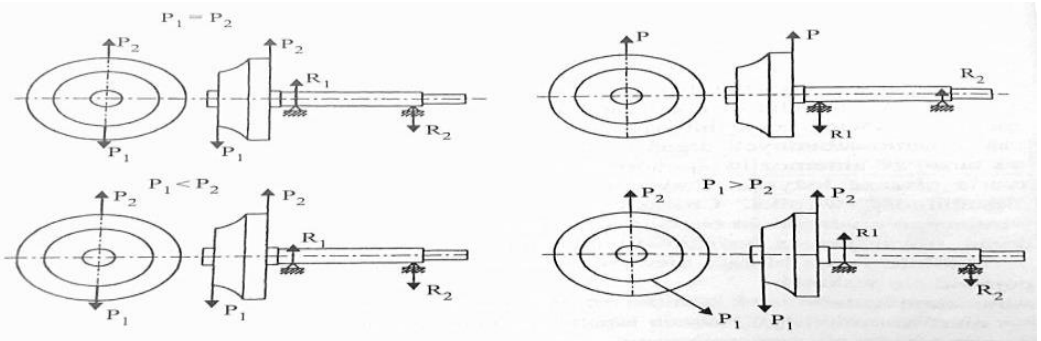

Fig.6. Illustrates the dynamic balance of the turbocharger's rotor [1].

The force pair P1 and P2 as shown in Fig. 6 is in the same mode of working as the axis of the rotor. On a bearing-mounted balancing station, the reactions R1 and R2 are generated, which are in the same position as the above forces. They have equal values but opposite directions (R1=-R2). The location of the rotor, as well as the value of unbalanced mass, is used to verify the place and mass of the material, which has to be removed for proper dynamic balancing of turbocharger rotor [1].

The turbocharger of vehicle is balanced in two stages:

- $\quad$ stage I - Balancing the shaft with the turbine wheel and the compression wheel with nuts and spacers and seals (Fig. 7),

- $\quad$ stage II - balancing of the bearing-mounted turbocharger rotor in the compressor housing with oil system connected (Fig. 8).

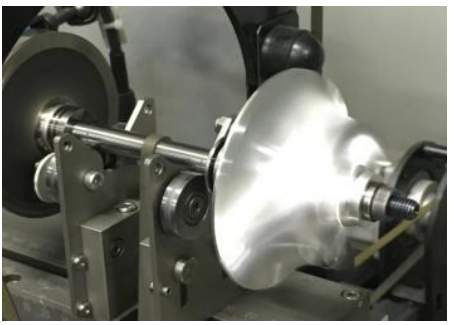

Fig. 7. Balancing the turbocharger shaft.

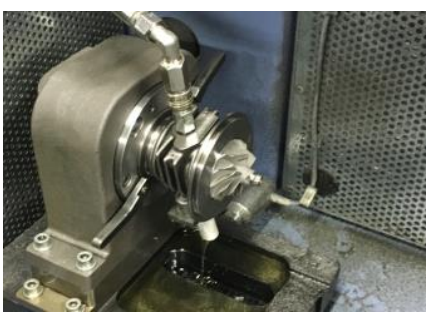

Fig. 8. Balancing the core of the turbocharger.

This type of balancing is the result of the recommended stricter requirements imposed by companies manufacturing turbo-charging devices. Correction of unbalance of turbochargers by "reduction of mass" certainly affects the structure of the balanced element, because excessive removal of material from the compression wheel or turbine wheel make them weak, which often causes cracking of these elements.

The following figures ( 9 and 10) show the points on the compression wheel from which the mass hass been reduced and the resulting wheel crack at the point where the unbalanced mass was gathered.
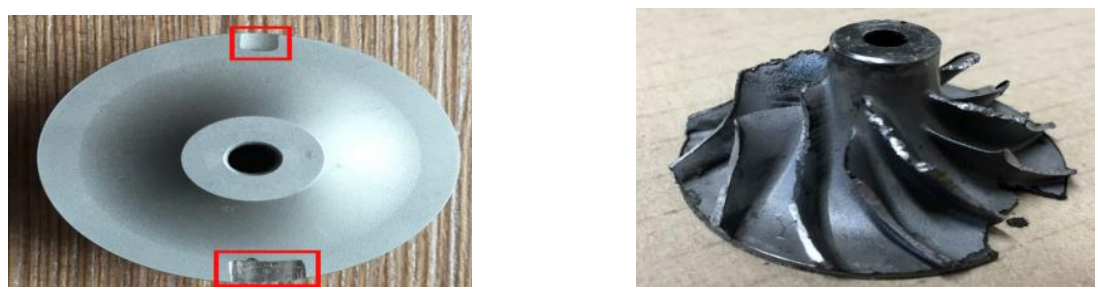

Fig. 9. Mass reduction points on the compression wheel. Fig.10. Cracked compression wheel.

\subsection{Dynamic balancing of the rotor by the 'mass addition' method}

Most of the damage to turbochargers is caused by breakage of the compression wheel; turbine; and also by breakage of the turbocharger shaft. Such defects are caused by 
improper exploitation of turbocharged combustion engines and incorrect regeneration of turbocharger components. Incorrect balancing of basic components has a negative impact on the construction and mechanical properties of turbocharger components. In order to prevent damage to materials which result from improper regeneration of turbocharger components, innovative tests are carried out in order to minimize the above problem. The method of 'mass addition' is carried out in two stages:

- first stage concerns the correction of the unbalanced mass of the turbocharger rotor including sealants and spacer nuts,

- second stage is based on balancing the rotating element (core of turbocharger) with bearings in the body of the device.

Two types of devices were used to perform these tests:

- Schenck TB Comfort slow-running balancing machine for the first stage of balancing,

- the second stage was carried out on a high-speed Schenck MBRS 110 machine.

Disassembly of balanced components and input of data of turbochargers into the system is the identical as in the traditional method using balancers for rotors and cores of turbochargers. The difference is in the way of correcting unbalanced masses of rotating parts. The process of unbalanced mass correction was carried out by using a special thermoresistant mass, which is designed, among other things, for the removal of exhaust gases and liquids whose temperature exceeds $1000^{\circ} \mathrm{C}$. Characteristic feature of this substance is a high adhesion coefficient and short time of mass fixation. During the reading of the value of the unbalanced mass of the rotating element, the heat-resistant mass is applied to the outside of the turbine wheel and compressed via an insulin syringe. Before application, the rotor surfaces were thoroughly cleaned and the amount of mass applied was verified on an electronic scale with an accuracy of $0.01 \mathrm{mg}$.

When the adhesive mass was bound, the turbocharger rotor was mounted in the core, which was subjected to strength tests on a device allowing to accelerate the rotating element to the speed of more than $2000001 / \mathrm{min}$.

The above method has been used for turbocharger number $038145702 \mathrm{E}$, which is used in vehicles of Volkswagen brand with engine capacity of $1900 \mathrm{~cm} 3$ and after removal of main components of turbocharger was verified its rotor in terms of balance.

In the first stage, the basic dimensions of the rotor, which are necessary for the test to be carried out correctly, were entered into the TB COMFORT balancing system. The following dimensions have been set:

- diameter of the compression wheel,

- height of the compression wheel,

- turbine wheel diameter,

- turbine wheel height,

- turbocharger shaft length,

- distance between turbocharger shaft and balancing sensors placed in supports.

Then the rotor of the turbocharger was rotated in order to verify its level of unbalance. The obtained value of unbalance correction was reduced by application of thermo-resistant mass with the use of insulin syringe (Fig. 11 and 12). 


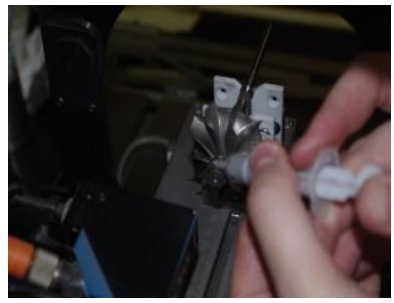

Fig. 11. Imposition of mass on the turbine.

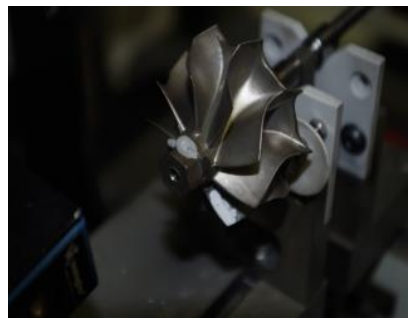

Fig. 12. Imposition of mass on the turbine wheel.

After the process of balancing the turbine wheel had been completed, the compression wheel was verified. The procedure was the same as in the case of the turbine wheel. The unbalance of the compression wheel was reduced by overlapping the same mass as that of the turbine wheel. The procedure of balancing the turbocharger rotor was carried out in a correct way, the size of unbalance was within the tolerance limits.

After the process of balancing the turbocharger's rotor, the balanced element was placed in the core of the turbocharger and mounted in the high speed Schenck MBRS110 balancing machine. During this process, the rotational speed of the rotating component exceeds $200000 \mathrm{rpm}$. At this stage of the test, the high rotational speed strength of the mass of the rotor, which is common during the daily operation of the turbocharged drive unit, has been verified. During this test, it was observed that at a rotational speed of $200000 \mathrm{rpm}$, the heat-resistant mass remained on the turbine wheel (Fig. 13), but broke out of the compression wheel (Fig. 14).
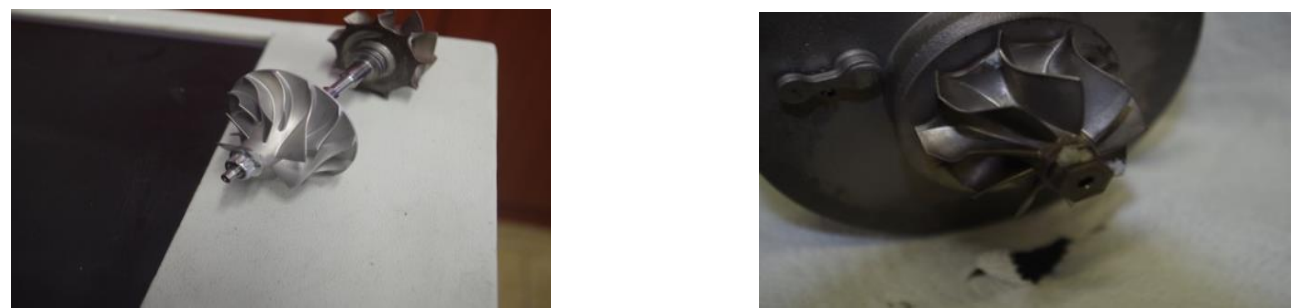

Fig. 13. Mass on the turbine wheel after compression test. Fig. 14. Ripped wheel massss.

Turbochargers of properly operated car engines do not require frequent repairs and reach mileages from 100000 to $300000 \mathrm{~km}$. They run reliably on heavy commercial vehicles, achieving mileages up to 500,000 kilometers and more. The reason of their possible earlier failures are usually mistakes in the exploitation and service of engines or damage to other systems cooperating directly with the turbochargers.

\section{Rational use of the turbocharger}

Turbocharger is an exhaust-driven compressor used for turbocharging combustion engines, which is used to increase engine power by increasing the amount of oxygen supplied to the combustion chamber - Fig. 15. The construction of the turbocharger is designed in such a way that it can cooperate with it without any problems during the engine lifetime.

The turbocharger does not need any specialist maintenance and its examination should be limited to a few basic steps included in the instructions for use of the turbocharger provided by the manufacturer. Typical damages to turbochargers are:

$>$ damages caused by foreign material,

$>$ Insufficient oil pressure,

$>$ temporary delays in oil delivery,

$>$ contaminated oil,

$>$ overheating, 
$>$ construction faults in the process of turbocharger manufacturing.

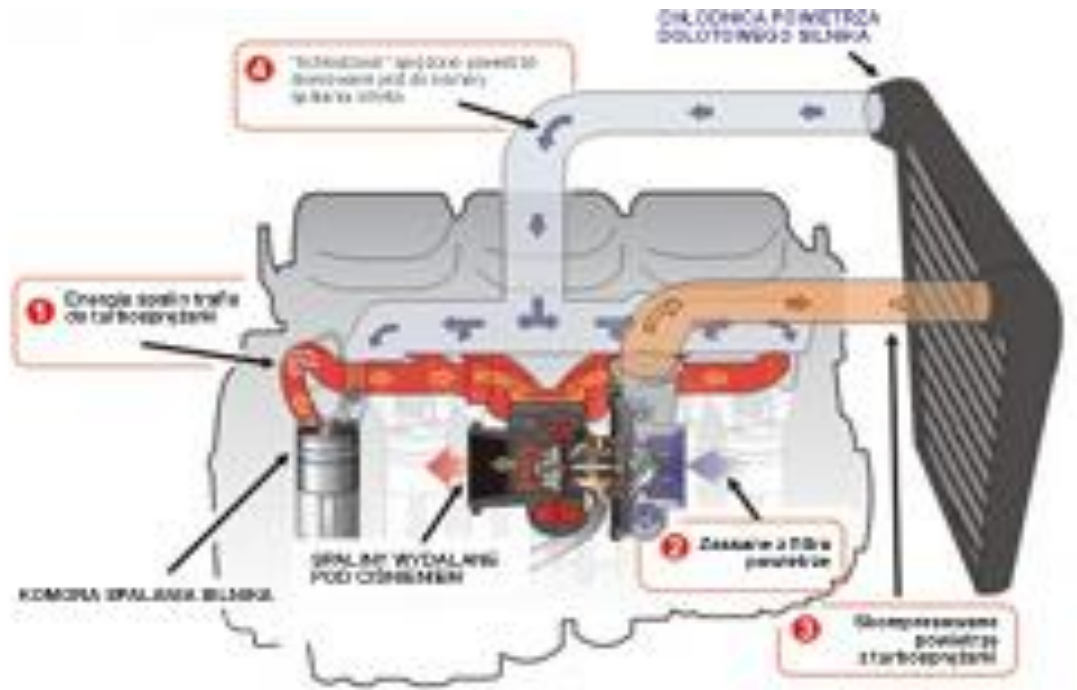

Fig.15. Diagram of turbo-diesel system [3].

There are obvious symptoms of turbocharger worn out:

$>$ sudden loss of power;

$>$ much louder operation (whistling);

blue exhaust smoke combined with rapid oil loss in the lubrication system;

$>$ oiling of the area around the turbocharger and in the air inlet ducts;

$>$ (,check engine”) error and low engine rpm.

Approximately $90 \%$ of damages of turbochargers are caused by their incorrect operation (use and maintenance). The main causes of turbocharger damages are following:

overheating of the turbocharger (after a long period of use, it is recommended to leave the unit cooled down, lubrication decays, charring of the lubricating oil, wear of bearings, clogging of oil ducts);

$>$ excessive load on the cold engine (cold oil is dense, the bearings are not lubricated);

$>$ use of not recommended oil by the manufacturer (preferably synthetic, for high operating temperatures);

$>$ exceeding the recommended oil change intervals (loss of lubricating properties);

$>$ low oil level (bearings, tilting in the sloping);

$>$ damaged air filter (sand, dust, high speed - wear);

$>$ defective turbocharger control (worn actuator and valve);

$>$ damage to the turbocharger seals (pumping oil into the engine, increase in rotation, uncontrolled damage).

Only the manufacturer of the turbocharger or authorized repair companies have the tools and personnel specialized in repairs of these devices.

The rational use of engines and turbochargers requires certain habits and simple maintenance to ensure the reliable operation of these units. The basic recommendations in this area are:

$>$ avoiding sudden engine stop after prolonged use;

$>$ do not use the full power of the engine immediately after it has been started up;

$>$ use of recommended oil, resistant to high temperatures and carbonization;

$>$ compliance with the timeliness of the oil change and the oil filter;

$>$ regular inspection of the engine oil; 
$>$ on-time replacement of air filters;

$>$ application of CERAMIZER (protective layer for shafts, rings, sleeves).

\section{Summary}

It is difficult to imagine a modern motor vehicle that is not equipped with an engine turbocharging system. The most common charging device is the turbocharger, which has gained its popularity thanks to its universality and flexibility. It is used both in internal combustion engines and in innovative hybrid drive units.

The most common cause of failure of turbochargers is unbalance of turbocharger's rotor. A characteristic feature of this problem is a linear increase in the amplitude of bearing vibrations, which depends on the rotational speed of the rotor. Incorrect balancing of the basic turbocharger-impeller element is caused by the following damages: cracked wheel of turbine or compression, damage to the turbocharger shaft, damage to thrust bearings and variable geometry system failure.

Analysing the proposed innovative method of balancing the rotor of turbocharger by adding heat-resistant mass we can conclude that the presented method is an interesting alternative to the current method of balancing turbochargers. Certainly, the probability of turbocharger failure during the reduction of unbalanced mass is minimized. Correction of the unbalanced mass of the rotor by the "mass addition" method does not affect the mechanical properties of the material and does not affect its structure. Thus, it does not cause cracks of rotating elements in the turbocharger.

Further research on this issue should identify the phenomenon of the loss of added mass from the compression wheel at a rotation of 200,000 min-1. In the initial analysis, this can be explained by the incorrect selection of glue for the material mass.

The proposed method aims to remove the problem of incorrect reduction of unbalanced weight. This problem appears in the form of cracks, i.e. damage to the basic components of the turbocharger's rotor. This involves expensive repairs to the main turbo-charging unit in the turbo-charging system.

The presented first results of research of the proposed solution confirm the fact that the right balance is the key aspect for the correct, failure-free use of the turbocharger.

Briefly indicated basic recommendations for rational use of car engines and turbochargers ensure safe and reliable operation of these systems.

\section{References}

1. J. Mysłowski, Pojazdy samochodowe - doładowanie silników. WKŁ Warsaw (2011).

2. H. Wojciechowski, Analiza metod badania turbosprężarek pojazdów samochodowych. Logistyka No. 4 (2015).

3. P. Bojarczuk, Doładowanie silników spalinowych - przegląd konstrukcji i diagnostyka. Poradnik serwisowy, No. 1 (2007).

4. J. Merkisz, M. Rychter, System OBD II jako przyszłe sposoby diagnozowania pojazdów. Eksploatacja i Niezawodność, No. 1 (2002).

5. J. Jaskólski, G. Budzik, A. Marciniec, Balancing of turbocharger rotors. Journal of Kones (2007).

6. M. Idzior, T. Bieliński, T. Borowczyk, W. Karpiuk, Analiza wpływu warunków eksploatacji na stan techniczny turbosprężarek doładowanych silników spalinowych. Logistyka (2010).

7. J. Kaszkowiak, S. Borowski, E. Dulcet, M. Zastępowski, Analiza uszkodzeń turbosprężarek. Logistyka (2015).

8. B. Żółtowski, C. Cempel, Inżynieria diagnostyki maszyn. Polskie Towarzystwo Diagnostyki Technicznej. Instytut Technologii Eksploatacji. (2004).

9. B. Żółtowski, Badania dynamiki maszyn. ATR Bydgoszcz (2002). 
10. B. Żółtowski, Podstawy diagnostyki maszyn. ATR Bydgoszcz (1996).

11. B. Żółtowski, M. Łukasiewicz, Wibroakustyka maszyn $w$ laboratorium. ATR Bydgoszcz (2005).

12. M. Żółtowski, Informatyczne systemy zarzadzania $w$ inżynierii produkcji. ITE - PIB, Radom (2011). 